\title{
Evaluation of Rational Drug Use based on Indicators of Diseases and Facilities at Community Health Centers in Districts in Semarang
}

Nisa Febrinasari*
Abdur Rosyid
Leny Angelina
Department of Pharmacy, Universitas
Islam Sultan Agung Semarang,
Semarang, Central Java, Indonesia
"email: nisafebrie@unissula.ac.id
Keywords:
Community Health Center
Facility Indicator
Prescribing Indicator
Rational Drug Use
Semarang

\begin{abstract}
Rational drug use (RDU) is an indicator to evaluates a treatment given to patients, like proper medication, precise diagnosis, precise dosing. Community Health Center $(\mathrm{CHC})$ has the risk of irrational drug use. In this study, researchers selected $\mathrm{N}$ and $\mathrm{BL} \mathrm{CHC}$, aiming to evaluate the prescribing indicators based on three diseases which are nonpneumonia acute respiratory infection (ARI), non-specific diarrhea and myalgia, and the facility indicators with DOEN (list of essential national medicines) availability and 20 mandatory drugs. This research was a descriptive-analytical study with cross-sectional methods where the data retrieval of the prescribing is taken from January to December 2018. The study used the normality test and homogeneity test before independent sample T-test, from the third outcome of the test, the $\mathrm{N}$ and BL CHC could be said to differ significantly of RDU. It can be concluded that rational drug use is reviewed from a prescribing indicator based on disease and facility indicator. The results of RDU are rational in N CHC, in contrast with $\mathrm{BL} \mathrm{CHC}$ which is not rational with the results of the RDU in N CHC is $101.44 \%$ and $\mathrm{BL} \mathrm{CHC}$ is $89.81 \%$. The results of $\mathrm{N} \mathrm{CHC}$ is better than $\mathrm{BL} \mathrm{CHC}$, which both $\mathrm{CHC}$ have fulfilled the target of the government, for $68 \%$ in 2018 . In both CHCs for the facility indicator, there are a DOEN and 20 essential medicines.
\end{abstract}

Received: July 24th 2019

Accepted: October 22nd 2019

Published: November 14th 2019

(C) 2019 Nisa Febrinasari, Abdur Rosyid, Leny Angelina. Published by Institute for Research and Community Services Universitas Muhammadiyah Palangkaraya. This is an Open Access article under the CC-BY-SA License (http://creativecommons.org/licenses/by-sa/4.0/). DOI: https://doi.org/10.33084/bjop.v2i2.875.

\section{INTRODUCTION}

Rational drug use (RDU) is the use of drugs that are in accordance with the criteria, such as the right medicine, the right diagnosis, the right indication, how to use it, the time of administration, the right condition of the patient, timely administration and alert to side effects (Smeulers et al., 2015). World Health Organization (WHO) estimates that almost more than half of all drugs in the world are given, sold and prescribed inappropriately, and half of the patient's misuse drugs (Ministry of Health of the Republic of Indonesia, 2017). Where it is known that irrational use of drugs, as well as negative impacts, is greater than the benefits, received by patients, side effects and antibiotic resistance occur, besides the costs are not affordable/too expensive (Ofori-Asenso \& Agyeman, 2016). Medication prescription is usually done as the last step in patient and doctor consultation, but there are still frequent therapeutic errors (medication errors)/therapy (FitzGerald, 2009). This error usually occurs in prescribing, where when choosing the type of drug, dosage, how to use it, writing is challenging to read, where the incident becomes a supporting factor in increasing therapeutic errors (Simatupang, 2012).

Rational Drug Use is one of the things that needs to be done to get maximum treatment (Basaran \& Akici, 2012). Evaluation of RDU is reviewed from prescription based on disease, according to Ministry of Health of the Republic of Indonesia (2017), which has been listed using 
three diseases, namely non-pneumonia acute respiratory infection (ARI), non-specific diarrhea and Myalgia, besides according to the Semarang City Health Office, that three diseases are included prevalence of the top 10 diseases in Semarang Community Health Center (CHC) in 2017. In the RDU module, it said in the facility indicators there was three-module which is patient knowledge about the correct dosage, availability of Essential Medication List (DOEN), and availability of critical drugs (Ministry of Health of the Republic of Indonesia, 2013). Here the researcher uses two facility indicators, namely the availability of a List of Essential Medicines and critical drugs.

The Community Health Center is one type of first-level health care facility that has an essential role in the national health system, specifically the health efforts subsystem, seeing that the $\mathrm{CHC}$ has a significant risk of irrational use of drugs (Ofori-Asenso \& Agyeman, 2016). Here, the researchers choose the $\mathrm{N}$ and $\mathrm{BL} \mathrm{CHC}$ for data collection related to the evaluation of RDU in terms of prescription based on diseases and facilities, as for the reasons for choosing the $\mathrm{N}$ and $\mathrm{BL} \mathrm{CHC}$, namely at the two $\mathrm{CHCs}$ which were the largest in the sub-district. The BL CHC is located in North Semarang Subdistrict, while the N CHC is in West Semarang Subdistrict. Also, the two CHCs are both in urban areas and at the two CHCs are in densely populated areas, for the BL CHC has a population of 51,889 people and $\mathrm{N} \mathrm{CHC} \mathrm{46,383} \mathrm{people,} \mathrm{besides} \mathrm{that} \mathrm{the}$ two CHCs have never been evaluated before (Semarang City Health Office, 2015).

The research was conducted aimed at looking at the rationality in the use of drugs in Semarang City $\mathrm{CHC}$, two of them is $\mathrm{N}$ and BL CHC, by looking at three diseases, namely non-pneumonia ARI, non-specific diarrhea and Myalgia, known in the three diseases including the top ten diseases often found in $\mathrm{CHC}$, besides that, also looking at the facilities, to see whether or not there is a DOEN or 20 essential medicines for the $\mathrm{CHC}$.

\section{MATERIALS AND METHODS}

This study was an analytical descriptive study using the cross-sectional method. Retrospective method for retrieving prescription indicator data and prospecting for facility indicator data collection. Free variables are prescribing indicators and RDU facilities, while for Bound variables are RDU.

The population of this study is the number of all prescriptions from all diseases in one year in January December of 2018 in N and BL CHC of Semarang City. From the total number of prescription samples in $\mathrm{N}$ and BL CHC that will be taken, those that meet the inclusion criteria. Data analysis was performed using statistical test software. The a value used is $5 \%$ because the researcher used a 95\% confidence interval.

\section{RESULTS AND DISCUSSION}

Data collection was carried out in the two CHCs from January to December 2018, in N CHC there were 4,739 prescriptions for all three diseases, respectively for nonpneumonia ARI 2,709 prescriptions, non-specific diarrhea 672 prescriptions and Myalgia 1,358 prescriptions. Whereas for $\mathrm{BL}$ CHC for all prescriptions for the three diseases, 3,761 prescriptions and each disease were found in non-pneumonia ARI 2,583 prescriptions, non-specific diarrhea 363 prescriptions, Myalgia 815 prescriptions, if seen from the working area at BL CHC of 51,130 people, whereas in N CHC is 55,739 people. This makes $\mathrm{NCHC}$ having more prescriptions in 2018 than BL CHC.

In prescribing data taken at $\mathrm{N}$ and $\mathrm{BL} \mathrm{CHC}$, total prescriptions were obtained for the three diseases, of which $\mathrm{N} \mathrm{CHC} \mathrm{had} \mathrm{a} \mathrm{more} \mathrm{significant} \mathrm{total} \mathrm{prescription}$ 
for the three diseases, compared to BL CHC. The data is presented in Table I.

Table I. Total prescription for N and BL CHC during 2018

\begin{tabular}{|c|c|c|}
\hline \multirow{2}{*}{ Type of disease } & \multicolumn{2}{|c|}{ Number of Prescription } \\
\hline & N CHC & BL CHC \\
\hline Non-pneumonia ARI & 2,709 & 2,583 \\
\hline Non-specific diarrhea & 672 & 363 \\
\hline Myalgia & 1,358 & 815 \\
\hline Total prescriptions & 4,739 & 3,761 \\
\hline
\end{tabular}

Data retrieval is done in a retrospective manner from January to December 2018 for prescription, while for prospective indicators of facility collection. After retrieving the data, it is then processed using Microsoft Excel to find out the results of the percentage of antibiotic use in non-pneumonia ARI and non-specific diarrhea and the use of injection of Myalgia, mean drug items and percentage of RDU. The maximum use of antibiotics in non-pneumonia ARI is $20 \%$, non-specific diarrhea is $8 \%$, and injection of Myalgia is 1\%, while for average drug items is a prescription of 2.6 (Ministry of Health of the Republic of Indonesia, 2017).

The use of antibiotics in non-pneumonia ARI at the BL $\mathrm{CHC}$ is more than the parameters. The parameter for non-pneumonia ARI is a maximum of $20 \%$ according to the Ministry of Health of the Republic of Indonesia (2017), which is only in January, July and October that do not meet the parameters. In processing the data, which is obtained from the percentage of the use of nonpneumonia ARI antibiotics in N CHC is stated rationally on a monthly basis which is less than $20 \%$ while in BL $\mathrm{CHC}$ there are three months which are declared irrational in antibiotic use, and nine months are said to meet from the parameter. This happens because of the frequent administration of antibiotics in non-pneumonia ARI which does not need antibiotics because nonpneumonia ARI is a disease caused by viruses or commonly known in the community with the common cold (Sauriasari et al., 2017). It is said that N CHC is rational because the prescription is taken according to the requirements, i.e. without any disease or accompanying diagnosis in each prescription, besides that the doctor does not give antibiotics but not all, which still found some who use antibiotics in some prescription. The data on antibiotic use for non-pneumonia ARI are presented in Table II.

Table II. Percentage of antibiotic use in non-pneumonia ARI in $\mathrm{N}$ and BL CHC Semarang

\begin{tabular}{clcccc}
\hline \multirow{2}{*}{ No } & \multirow{2}{*}{ Month } & \multicolumn{2}{c}{ N CHC } & \multicolumn{2}{c}{ BL CHC } \\
\cline { 3 - 6 } & & Amount & \% & Amount & \% \\
\hline 1 & January & 9 & 3.22 & 37 & $23.56^{*}$ \\
2 & February & 7 & 2.92 & 44 & 16.60 \\
3 & March & 8 & 2.2 & 68 & 18.18 \\
4 & April & 7 & 3.11 & 19 & 8.29 \\
5 & May & 6 & 3.07 & 37 & 14.56 \\
6 & June & 5 & 4.06 & 23 & 15.43 \\
7 & July & 7 & 3.25 & 51 & $24.05^{*}$ \\
8 & August & 6 & 2.4 & 42 & 16.66 \\
9 & September & 7 & 3.64 & 23 & 16.42 \\
10 & October & 6 & 3.46 & 41 & $20.29^{*}$ \\
11 & November & 6 & 2.88 & 40 & 18.43 \\
12 & December & 8 & 3.22 & 17 & 12.87 \\
\hline \multicolumn{5}{c}{ Average } & 3.12 \\
\hline
\end{tabular}

Note: * irrational

Antibiotics are still often found in non-specific diarrhea at BL compared to N CHC. The parameters for non-specific diarrhea are a maximum of $8 \%$ and only in March, May and September that the parameters are met, and the rest do not meet the parameters. The use of non-specific Diarrhea antibiotics in N CHC was expressed according to parameters, whereas in BL CHC, nine months did not meet the parameters in 2018. Where the percentage of antibiotic use in non-specific diarrhea was a maximum of $8 \%$ (Ministry of Health of the Republic of Indonesia, 2017). Non-specific diarrhea is caused by rotavirus, which can heal on its own (Crawford et al., 2017). In interviews with pharmacists in N CHC, they fulfilled the parameters because from the pharmacy department itself was polluting each prescription, other than that the authorized person was very rarely given antibiotics, which were usually given Oral Rehydration Solutions (ORS) and zinc. Data on antibiotic use for non-specific diarrhea are presented in Table III. 
Table III. Percentage of antibiotic use in non-specific diarrhea in $\mathrm{N}$ and BL CHC Semarang

\begin{tabular}{clcccc}
\hline \multirow{2}{*}{ No } & \multirow{2}{*}{ Month } & \multicolumn{2}{c}{ N CHC } & \multicolumn{2}{c}{ BL CHC } \\
\cline { 3 - 6 } & Amount & \% & Amount & \% \\
\hline 1 & January & 3 & 3.89 & 5 & $21.73^{*}$ \\
2 & February & 2 & 3.92 & 8 & $18.18^{*}$ \\
3 & March & 2 & 3.84 & 3 & 6.38 \\
4 & April & 2 & 3.77 & 3 & $11.53^{*}$ \\
5 & May & 2 & 4 & 0 & 0 \\
6 & June & 2 & 3.63 & 2 & $15.38^{*}$ \\
7 & July & 2 & 3.38 & 2 & 7.14 \\
8 & August & 2 & 3.38 & 9 & $24.32^{*}$ \\
9 & September & 2 & 3.7 & 5 & $25^{*}$ \\
10 & October & 2 & 3.63 & 8 & $26.66^{*}$ \\
11 & November & 2 & 3.57 & 9 & $28.12^{*}$ \\
12 & December & 2 & 3.92 & 6 & $19.35^{*}$ \\
\hline \multicolumn{2}{c}{ Average } & \multicolumn{5}{c}{} & $16.98^{*}$ \\
\hline
\end{tabular}

Note: * irrational

In the injection of Myalgia, the results for both $\mathrm{CHCs}$ met the parameters, where the parameters for Myalgia were 1\% (Ministry of Health of the Republic of Indonesia, 2017). As for the second yield of $\mathrm{CHC}$ is $0 \%$. This happened because there had been no injection of Myalgia since a long time ago. In addition, the role of the government which was suppressing high injection through the procurement of drugs, among others, knowledge from the community and doctors who went to the doctor did not have to be injected (Kardela et al., 2014), especially sometimes elderly patients have an illness which cannot be given injection by injection and also there is no injection drug available for my happiness in both CHCs. In both CHCs, no injection was given for the injection, but sometimes in $\mathrm{CHC}$ in the administration of the drug, there were still up to four types of drugs, such as (neurovitamin/B1, B6, B12 + analgesic). Data on injection use for Myalgia are presented in Table IV.

Table IV. Percentage of injection use in Myalgia in N and BL CHC Semarang

\begin{tabular}{clcccc}
\hline \multirow{2}{*}{ No } & \multirow{2}{*}{ Month } & \multicolumn{2}{c}{ N CHC } & \multicolumn{2}{c}{ BL CHC } \\
\cline { 3 - 6 } & & Amount & \% & Amount & $\mathbf{\%}$ \\
\hline 1 & January & 0 & 0 & 0 & 0 \\
2 & February & 0 & 0 & 0 & 0 \\
3 & March & 0 & 0 & 0 & 0 \\
4 & April & 0 & 0 & 0 & 0 \\
5 & May & 0 & 0 & 0 & 0 \\
6 & June & 0 & 0 & 0 & 0 \\
7 & July & 0 & 0 & 0 & 0 \\
8 & August & 0 & 0 & 0 & 0 \\
9 & September & 0 & 0 & 0 & 0 \\
10 & October & 0 & 0 & 0 & 0 \\
\hline
\end{tabular}

\begin{tabular}{cccccc}
\hline 11 & November & 0 & 0 & 0 & 0 \\
12 & December & 0 & 0 & 0 & 0 \\
\hline Average & & 0 & & 0 \\
\hline
\end{tabular}

In the results of the average item per prescription sheet, the two CHCs did not meet the parameters, only one month fulfilled the parameters, namely in March with 1.96 item per prescription in $\mathrm{BLCHC}$, whereas in $\mathrm{NCHC}$ in one year there were no parameters. The parameters for the average item per sheet are a prescription maximum of 2.6 (Ministry of Health of the Republic of Indonesia, 2017). This is likely to occur due to the presence of polypharmacy at each $\mathrm{CHC}$, which sometimes doctors focus more on symptoms that occur than diagnoses or information obtained is lacking (Kukreja et al., 2013). Besides, the results of interviews with pharmacists in $\mathrm{N}$ $\mathrm{CHC}$, where patients feel that the administration of a small number of drugs ( $2 / 3$ of the drugs) is considered insufficient so that the pharmacist gives additional drugs, which is one of the causes of polypharmacy. Data on average drug items prescribed per prescription sheet are presented in Table $\mathbf{V}$.

Table V. Number of average drug items prescribed per prescription sheet in N and BL CHC Semarang

\begin{tabular}{clcc}
\hline \multirow{2}{*}{ No } & \multirow{2}{*}{ Month } & \multicolumn{2}{c}{$\begin{array}{c}\text { Number of average drug items } \\
\text { prescribed }\end{array}$} \\
\cline { 3 - 4 } & & N CHC & BL CHC \\
\hline 1 & January & $2.77^{*}$ & $3.01^{*}$ \\
2 & February & $3.00^{*}$ & $3.09^{*}$ \\
3 & March & $2.80^{*}$ & 1.96 \\
4 & April & $3.12^{*}$ & $3.00^{*}$ \\
5 & May & $2.91^{*}$ & $3.16^{*}$ \\
6 & June & $3.22^{*}$ & $3.26^{*}$ \\
7 & July & $2.71^{*}$ & $3.21^{*}$ \\
8 & August & $2.68^{*}$ & $3.22^{*}$ \\
9 & September & $2.66^{*}$ & $3.38^{*}$ \\
10 & October & $3.07^{*}$ & $3.47^{*}$ \\
11 & November & $2.84^{*}$ & $3.34^{*}$ \\
12 & December & $2.95^{*}$ & $3.08^{*}$ \\
\hline \multicolumn{5}{c}{ Average } & $2.89^{*}$ & $3.09^{*}$ \\
\hline
\end{tabular}

Note: * irrational

The results of the calculation of the RDU percentage in each $\mathrm{CHC}$ showed different results which at $\mathrm{N} \mathrm{CHC}$ yielded $101.44 \%$, while the BLCHC amounted to $89.81 \%$, seen from these results where both $\mathrm{CHCs}$ met the target and even exceeded. City or sub-district governments 
provide a target of $68 \%$ in 2018 for the percentage of RDU (Ministry of Health of the Republic of Indonesia, 2018). Where the use of antibiotics in cases of ARI nonpneumonia and non-specific diarrhea antibiotics are often found in their use in BL CHC, which makes it irrational. The results of the interview with pharmacist assistants at BL CHC, which still uses the $30 \%$ parameter in non-pneumonia ARI and non-specific diarrhea which makes the two diseases exceed the parameters. This is due to lack of information obtained by the pharmaceutical installation, which is associated with the most recent use of parameters, namely for nonpneumonia ARI by $20 \%$ and non-specific diarrhea $8 \%$, besides that for injection of Myalgia it is no longer allowed. This is because there is no pharmacist there at $\mathrm{BL} \mathrm{CHC}$, unlike N CHC where there is a pharmacist, where N CHC is hospitalized, besides the pharmacist's role is needed at any pharmacy installation especially at $\mathrm{BL} \mathrm{CHC}$, to prevent irrational use of drugs and polypharmacy in the community. Data on Percentage of RDU are presented in Table VI.

Table VI. Percentage of RDU in N and BL CHC Semarang

\begin{tabular}{clcc}
\hline \multirow{2}{*}{ No } & \multirow{2}{*}{ Month } & \multicolumn{2}{c}{ \% of RDU } \\
\cline { 3 - 4 } & & N CHC & BL CHC \\
\hline 1 & January & 103.57 & 88.43 \\
2 & February & 99.58 & 84 \\
3 & March & 103.37 & 98.03 \\
4 & April & 97.39 & 94.78 \\
5 & May & 101.09 & 87.11 \\
6 & June & 95.34 & 89.15 \\
7 & July & 104.77 & 81.3 \\
8 & August & 105.57 & 82.03 \\
9 & September & 105.46 & 86.2 \\
10 & October & 98.21 & 78.15 \\
11 & November & 102.52 & 80.51 \\
12 & December & 100.35 & 93.16 \\
\hline \multicolumn{2}{c}{ Average } & 101.44 & 86.9
\end{tabular}

The results of the normality test in both CHCs are said to be normally distributed, as well as the homogeneity test. Which if the two tests, namely the normality test and the homogeneity test are normally distributed, then proceed with the T-test, where the table shows the results of the Ttest which is $p 0.000$, which if $p<0.05$ shows results that are not significantly different in both CHCs (Dahlan, 2014). Statistical test results are presented in Table VII.

Table VII. Statistical test results

\begin{tabular}{rccc}
\hline CHC & Normality test & Homogeneity Test & T-test \\
\hline $\mathrm{N}$ & 0.605 & 0.145 & 0.000 \\
$\mathrm{BL}$ & 0.976 & & \\
\hline
\end{tabular}

In the facility indicator, this study looked at the availability of a DOEN and 20 essential drugs at $\mathrm{CHC}$. And it is known that both CHCs has DOEN and 20 essential drugs. From the results of interviews with pharmacist assistants which in the supply of 20 essential drugs, the drug is given according to the needs or consumption of each $\mathrm{CHC}$, such as the amoxicillin tab, amoxicillin syrup and paracetamol, while in the antituberculosis drug case or program, and for injection is rarely used so for each $\mathrm{CHC}$ it is usually only a box. Ministry of Health of the Republic of Indonesia targets $100 \%$ in the implementation of DOEN, which aims to improve security, rational use of drugs and accuracy, which is at the same time to level, expand and improve the quality of health services (Kardela et al., 2014). Data on facility indicator are presented in Table VIII.

Table VIII. Facility indicator in N and BL CHC Semarang

\begin{tabular}{cccc}
\hline \multirow{2}{*}{ No } & \multirow{2}{*}{ Facility indicator } & \multicolumn{2}{c}{ Presence of facility indicator } \\
\cline { 3 - 4 } & & N CHC & BL CHC \\
\hline 1 & DOEN & Yes & Yes \\
2 & 20 essential drugs & Yes & Yes \\
\hline
\end{tabular}

\section{CONCLUSION}

This study was successful in showing that the use of drugs in N CHC was rational, while for BL CHC it was not rational based on prescription indicators based on disease and facility indicators, both CHCs on facility indicators were stated to meet the criteria. The percentage of drug use in N CHC alone is $101.44 \%$, which is better than BL CHC, which is only $89.81 \%$. 


\section{REFERENCES}

Basaran, N.F., Akici, A. 2012. Patients' experience and perspectives on the rational use of drugs in Turkey: a survey study. Patient Preference and Adherence. 6:719-724. https://dx.doi.org/10.2147/PPA.S34922

Crawford, S.E., Ramani, S., Tate, J.E., Parashar, U.D., Svensson, L., Hagbom, M., Franco, M.A., Grenberg, H.B., O'Ryan, M., Kang, G., Desselberger, U., Estes, M.K. 2017. Rotavirus infection. Nature Reviews Disease Primers. 3:17083.

https:/ /dx.doi.org/10.1038/nrdp.2017.83

Dahlan, M.S. 2014. Statistik Untuk Kedokteran dan Kesehatan Edisi 6. Jakarta: Epidemiologi Indonesia.

FitzGerald, R.J. 2009. Medication errors: the importance of an accurate drug history. British Journal of Clinical Pharmacology. 67(6):671-675. https://dx.doi.org/10.1111/j.1365-

2125.2009.03424.x

Kardela. W., Retnosari, A., Sudibyo, S. 2014. Perbandingan Penggunaan Obat Rasional Berdasarkan Indikator WHO di Puskesmas Kecamatan antara Kota Depok dan Jakarta Selatan. Jurnal Kefarmasian Indonesia. 4(2):91102.

Kukreja, S., Kalra, G., Shah, N., Shrivastava, A. 2013. Polypharmacy in Psychiatry: A Review. Mens Sana Monographs. 11(1):82-99. https:/ /dx.doi.org/10.4103/0973-1229.104497

Ministry of Health of the Republic of Indonesia. 2011. Modul Penggunaan Obat Rasional. Jakarta: Ministry of Health of the Republic of Indonesia

Ministry of Health of the Republic of Indonesia. 2013. Daftar Obat Esensial Nasional 2013. Jakarta: Ministry of Health of the Republic of Indonesia

Ministry of Health of the Republic of Indonesia. 2017. Laporan Akuntabilitas Kinerja 2016. Jakarta: Directorate General of Pharmaceuticals and Medical Devices Ministry of Health of the Republic of Indonesia

Ministry of Health of the Republic of Indonesia. 2018. Laporan Kinerja Direktorat Jenderal Kefarmasian dan Alat Kesehatan Tahun 2017. Jakarta: Directorate General of Pharmaceuticals and
Medical Devices Ministry of Health of the Republic of Indonesia.

Ofori-Asenso, R., Agyeman, A.A. 2016. Irrational Use of Medicines - A Summary of Key Concepts. Pharmacy. 4(4):35. https://dx.doi.org/10.3390/pharmacy40 40035

Sauriasari, R., Aulia, A.A.H., Swastika, A. 2017. Evaluasi kesesuaian penulisan resep pada kasus ISPA non-pneumonia di poli MTBS Puskesmas Kecamatan Cengkareng Jakarta. Pharmaceutical Sciences $\mathcal{E} \quad$ Research. 4(2):81-87. http:/ / dx.doi.org/10.7454/psr.v4i2.3770

Semarang City Health Office. 2015. Profil Kesehatan Kota Semarang Tahun 2014. Semarang: Semarang City Health Office

Simatupang, A. 2012. Pedoman WHO Tentang Penulisan Resep yang Baik sebagai Penggunaan Obat yang Rasional. Jakarta: Faculty of Medicine, Indonesian Christian University.

Smeulers, M., Verweij, L., Maaskant, J.M., de Boer, M., Krediet, C.T.P., van Dijkum, E.J.M.N., Vermeulen, H. 2015. Quality Indicators for Safe Medication Preparation and Administration: A Systematic Review. PLoS One. 10(4):e0122695. https:/ / dx.doi.org/10.1371/journal.pon e.0122695 